\title{
Relationship of ABO Blood Groups with Body Mass Index
}

\author{
Sarah Abdulateef Kadhum¹, Wafaa Abd Ali Hattab², Musaab Majid Abdulwahhab ${ }^{2}$ \\ ${ }^{I}$ M.Sc. (Al-Bayan University-College of Nursing-Adult Nursing Department), \\ ${ }^{2}$ Ph.D. (University of Baghdad-College of Nursing-Adult Nursing Department)
}

\begin{abstract}
Background: Obesity predisposing factors have been raised as a major concern of researchers due to the consequences of obesity on health such as diabetes, hypertension, and depression, $\mathrm{ABO}$ blood groups linked to many diseases, so may affect directly or indirectly on the incidence of obesity.
\end{abstract}

Objectives: The study aims to find out the association of ABO blood groups with body mass index.

Method: A cross-sectional study was conducted with a non-probability purposive sample of 2604 young adulthood age (18-25 years) that does not have previous surgery or chronic diseases through an electronic questionnaire in Iraq. A statistical package for social science (SPSS) program, version 24 was used for descriptive and inferential statistics.

Results: Blood group O was a common frequency in people with increased body mass index, so high statistically significant association recorded $(\mathrm{p} \leq 0.001)$. In addition, most of the subject $(86.6 \%)$ have positive rhesus $(\mathrm{Rh}+)$.

Conclusions: People with blood group $\mathrm{O}$ and positive RH were most vulnerable to increase their body mass index.

Keywords: Relationship, ABO blood groups, Body Mass Index.

\section{Introduction}

It is really important to identify the obesity predisposing factors; Obesity has major consequences on the physical and psychosocial aspects. Hypertension ${ }^{[2]}$, diabetes mellitus ${ }^{[3]}$, cardiovascular diseases ${ }^{[4]}$, depression, and anxiety ${ }^{[5]}$ may develop as a result of obesity; this study tries to find out if the ABO blood groups are a factor to develop obesity. Many studies demonstrate that the blood groups correlate to several diseases such as osteoporosis, thyroid disorder, and hyper-cholesterolemia. ${ }^{[6,7]}$ These studies help to identify

\section{Corresponding Author:}

\section{Musaab Majid Abdulwahhab}

Ph.D. (University of Baghdad-College of Nursing-

Adult Nursing Department)

e-mail:musaab@conursing.uobaghdad.edu.iq the diseases vulnerability and take preventive measures to decrease the incidence and that what are going to do in this study. If we recognize the blood group that has the highest vulnerability to develop obesity so we can take more attention to help prevent people with this blood group to develop obesity.

Objectives of the Study: The study aims to find out the association between blood groups with body mass index.

\section{Materials and Method}

Design of the Study: A cross-sectional study was conducted with a non-probability purposive sample of 2604 young adulthood age (18-25 years) that does not have previous surgery or chronic diseases through an electronic questionnaire in Iraq.

Study Instrument: BMI was calculated by division body weight in Kilogram on the height in Metric Square 
$\left(B M I=\frac{\text { Bodyweight }(\mathrm{Kg})}{\text { Height }(\mathrm{m} 2)},\right)$, and WHO classification of BMI was adopted as shown in (Table 1).

Table 1: Classification of BMI

\begin{tabular}{|c|c|}
\hline BMI & Classification \\
\hline$<18.5$ & Underweight \\
\hline $18.5-24.9$ & Normal weight \\
\hline $25.0-29.9$ & Overweight \\
\hline $30.0-34.9$ & Class I obesity \\
\hline $35.0-39.9$ & Class II obesity \\
\hline$\geq 40.0$ & Class III obesity \\
\hline
\end{tabular}

\section{Results}

Study results demonstrate that the blood group O records the highest percentage $(40.8 \%)$ of the study sample followed by $(34.8 \%),(22.6 \%),(12.8 \%)$ of A, B, and $\mathrm{AB}$ blood groups respectively (Figure 1). While the majority $(86.6 \%)$ of Rhesus was positive with (13.4\%) negative (Figure 2).

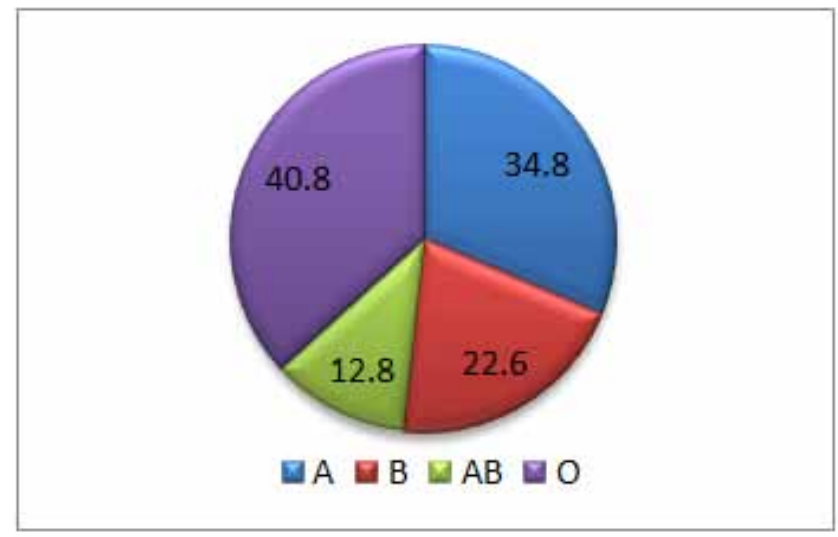

Figure 1: Distribution of ABO blood groups

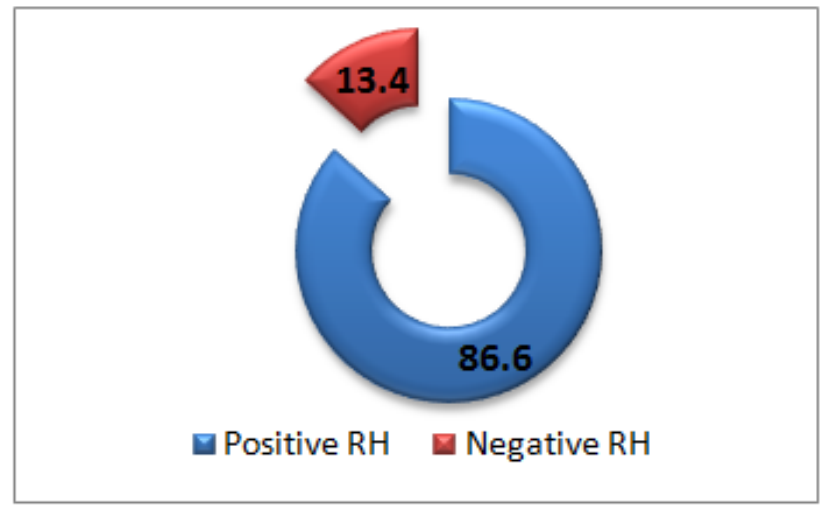

Figure 2: Distribution of Rhesus blood groups

Concerning the classification of BMI, most of the subject (54\%) was obesity 3 followed by Obesity 2 that record $(20 \%)$ and the lowest percentage $(4 \%)$ was recorded in an underweight group. In addition, the males were $(54.7 \%)$ and female (45.3\%). (Figure 4)

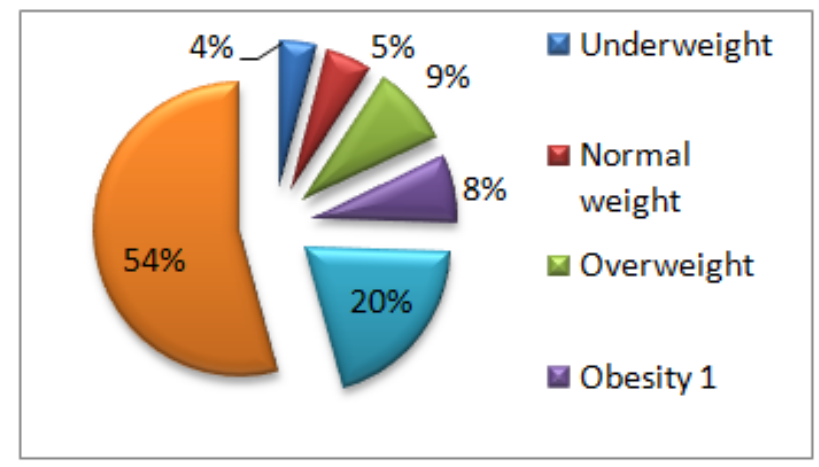

Figure 3: BMI Classification

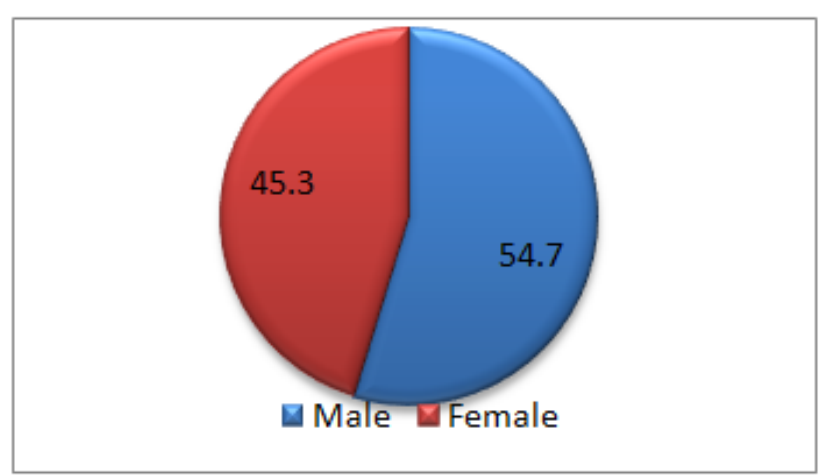

Figure 4: Distribution of Gender 
Table 2: Association of ABO blood groups with BMI

\begin{tabular}{|c|c|c|c|c|c|c|c|c|c|}
\hline \multirow[b]{2}{*}{$\begin{array}{l}\text { Blood } \\
\text { group }\end{array}$} & \multicolumn{6}{|c|}{ BMI classification } & \multirow{2}{*}{ Total } & \multirow[b]{2}{*}{ df } & \multirow{2}{*}{$\begin{array}{c}\text { Chi } \\
\text { Square }\end{array}$} \\
\hline & Underweight & Normal & Overweight & Obesity 1 & Obesity 2 & Obesity 3 & & & \\
\hline A & 23 & 31 & 43 & 29 & 144 & 351 & 621 & \multirow{5}{*}{15} & \multirow{5}{*}{0.000} \\
\hline $\mathrm{B}$ & 18 & 40 & 54 & 38 & 97 & 341 & 588 & & \\
\hline $\mathrm{AB}$ & 24 & 19 & 39 & 23 & 56 & 172 & 333 & & \\
\hline $\mathrm{O}$ & 40 & 46 & 93 & 104 & 228 & 551 & 1062 & & \\
\hline Total & 105 & 136 & 229 & 194 & 525 & 1415 & 2604 & & \\
\hline
\end{tabular}

Table 3: Differences of Rhesus toward BMI

\begin{tabular}{|l|l|c|c|c|c|}
\hline & RH & N & Mean & Std. Deviation & Std. Error Mean \\
\hline \multirow{3}{*}{ BMI } & Positive & 2256 & 63.4511 & 241.72271 & 5.08918 \\
\cline { 2 - 7 } & Negative & 348 & 45.0455 & 10.13388 & .54323 \\
\hline
\end{tabular}

\begin{tabular}{|c|c|c|c|c|c|c|c|c|c|c|}
\hline \multicolumn{11}{|c|}{ Independent Samples Test } \\
\hline & \multirow{3}{*}{$\begin{array}{l}\text { Levene's Test for } \\
\text { Equality of Variances }\end{array}$} & \multirow{3}{*}{$\mathbf{F}$} & \multirow{3}{*}{ Sig. } & \multicolumn{7}{|c|}{ t-test for Equality of Means } \\
\hline & & & & \multirow{2}{*}{$\mathbf{t}$} & \multirow{2}{*}{ df } & \multirow{2}{*}{ Sig. (2-tailed) } & \multirow{2}{*}{$\begin{array}{c}\text { Mean } \\
\text { Difference }\end{array}$} & \multirow{2}{*}{$\begin{array}{l}\text { Std. Error } \\
\text { Difference }\end{array}$} & \multicolumn{2}{|c|}{ 95\% Confid. } \\
\hline & & & & & & & & & Lower & Upper \\
\hline \multirow{2}{*}{ BMI } & Equal variances & 5.35 & .021 & 1.42 & 2602 & .156 & 18.40563 & 12.96156 & -7.010 & 43.82 \\
\hline & Not Equal variances & & & 3.59 & 23.73 & .000 & 18.40563 & 5.11809 & 8.36 & 28.44 \\
\hline
\end{tabular}

Std: standard, sig: significant, t: independent t test, df: degree of freedom, N: number of subject

The BMI record high statistically significant association with $\mathrm{ABO}$ blood group (Table 2) added to that, the Rhesus was being found a statistical difference with BMI (Table 3).

\section{Discussion}

The study aims to find out the impact of ABO blood groups on the incidence of obesity so we can provide preventive measures to that group with the highest vulnerability to obesity such as a healthy lifestyle and dietary habits.

The study result showed that the majority $(40.8 \%)$ of our sample was the blood group $\mathrm{O}$, followed by $\mathrm{A}$, $\mathrm{B}$, and $\mathrm{AB}$. In addition, the positive rhesus records the highest distribution $(86.6 \%)$ in comparison to negative rhesus. These results come along with many studies about the distribution of $\mathrm{ABO}$ blood groups in Iraq. ${ }^{[7-10]}$

The blood group $\mathrm{O}$ takes the highest frequency of increase body weight, the main cause of that result need to be more studied. However many articles demonstrate that the blood group $\mathrm{O}$ preferred the high protein diet with lean meat and fish ${ }^{[11]}$ added to that the type $\mathrm{O}$ blood group tend to Yoga and limited exercise in comparison to other blood groups that may prefer lifting weights and heavy exercise, eventually blood hormones level (such as catecholamines and cortisol) will be changed according to that exercise. ${ }^{[12]}$

The individuals with positive $\mathrm{Rh}$ record significant difference and obvious increase in their body weight when compared with peoples that have negative rhesus. Much more studies needed to explain that's fact and that may affected by race or specific geographical area. ${ }^{[13,14]}$

Acknowledgements: The authors thank to the University of Baghdad - College of Nursing for their cooperation to complete the official request for conducting the research.

Conflict of Interest: There are no conflict of interest concerning this research and the manuscript has not been submitted to another journal or publishing venue. 
Financial Resources: The authors have no affiliation with any organization with a direct or indirect financial interest in the subject matter discussed in the manuscript.

Informed Consent: Before filling the questionnaire, all participants were asked if they agree or disagree to participate in the research.

Conclusions:There are differences concerning physical and economic status between Americans and Iraqis, Americans record better physical activity and economic status. The psychological domain demonstrates that both communities had negative emotions, anxiety and depression as a result of COVID 19, curfew and social distancing.

Financial Disclosure: There is no financial disclosure.

Conflict of Interest: None to declare.

Ethical Clearance: All experimental protocols were approved under the Al-Bayan university-College of Nursing-Adult Nursing Department and all experiments were carried out in accordance with approved guidelines.

\section{References}

1. Bensimhon DR, Kraus WE, Donahue MP. Obesity and physical activity: a review. American heart journal. 2006 Mar 1; 151(3):598-603.

2. Re RN. Obesity-related hypertension. Ochsner J. 2009 Sep 21;9(3):133-6.

3. Lazar MA. How obesity causes diabetes: not a tall tale. Science. 2005 Jan 21; 307(5708):373-5.

4. Zalesin KC, Franklin BA, Miller WM, Peterson ED, McCullough PA. Impact of obesity on cardiovascular disease. Endocrinology and metabolism clinics of North America. 2008 Sep 1; 37(3):663-84.

5. Luppino FS, de Wit LM, Bouvy PF, Stijnen T, Cuijpers P, Penninx BW, Zitman FG. Overweight, obesity, and depression: a systematic review and meta-analysis of longitudinal studies. Archives of general psychiatry. 2010 Mar 1;67(3):220-9.
6. He M, Wolpin B, Rexrode K, Manson JE, Rimm $\mathrm{E}, \mathrm{Hu} \mathrm{FB}$, Qi L. ABO blood group and risk of coronary heart disease in two prospective cohort studies. Arteriosclerosis, thrombosis, and vascular biology. 2012 Sep;32(9): 4-20.

7. Eren $\mathrm{C}$, Çeçen S. An analysis on the association between $\mathrm{ABO}$ and $\mathrm{Rh}$ blood groups with obesity. Proceedings of the National Academy of Sciences, India Section B: Biological Sciences. 2019 Sep 2;89(3):1095-100.

8. Jaff MS. ABO and rhesus blood group distribution in Kurds. Journal of blood medicine. 2010;1:143.

9. Salih HA. Frequency distribution of abo blood groups and rh phenotypes of blood donors in Babylon Governorate-Iraq. Medical journal of Babylon. 2009; 6 (2):268-75.

10. Al-Khafaji SD. The frequencies of the ABO and Rh (D) blood groups in the Kurdish population of Iraq. Annals of human biology. 1976 Jan 1;3(2):89-91.

11. Al-Khatieeb MM, Al-Joubori SK, Taha SS. Association of ABO Blood Group and Rhesus Factor with Dental Malocclusion in a Population of Baghdad, Iraq. International Journal of Medical Research \& Health Sciences. 2018;7(1):165-9.

12. WatsonS. The Blood Type Diet, Reviewed by Christine Mikstas, RD, LD on July 22, 2020, Access at 29/August/2020:https://www.webmd. com/diet/a-z/blood-type-diet.

13. D'Adamo, Blood Group Genetics, Exercise and Stress, Reviewed and revised on: 02/12/2019, Access on 29/8/2020:https://www.dadamo.com/ txt/index.pl?1002.

14. Ahmed HO, Tawfiq SA, Mohammed DA, Abdulhakim SA, Omer MA, Nuri AM. Association of $\mathrm{ABO}$ group types to overweight and obesity: Based on six years of experience in two centers in Sulaimani governorate, Kurdistan Region/Iraq. Obesity medicine. 2019 Mar 1;13:21-5.

15. Smith S, Okai I, Abaidoo CS, Acheampong E. Association of ABO blood group and body mass index: A cross-sectional study from a Ghanaian population. Journal of nutrition and metabolism. 2018 Mar 27; 2018. 